\title{
The oxygenation of the atmosphere and oceans
}

\author{
Heinrich D. Holland* \\ Department of Earth and Planetary Sciences, Harvard University, Cambridge, MA 02138, USA
}

\begin{abstract}
The last 3.85 Gyr of Earth history have been divided into five stages. During stage 1 (3.85-2.45 Gyr ago (Ga)) the atmosphere was largely or entirely anoxic, as were the oceans, with the possible exception of oxygen oases in the shallow oceans.

During stage $2(2.45-1.85 \mathrm{Ga})$ atmospheric oxygen levels rose to values estimated to have been between 0.02 and $0.04 \mathrm{~atm}$. The shallow oceans became mildly oxygenated, while the deep oceans continued anoxic.

Stage $3(1.85-0.85 \mathrm{Ga})$ was apparently rather 'boring'. Atmospheric oxygen levels did not change significantly. Most of the surface oceans were mildly oxygenated, as were the deep oceans.

Stage $4(0.85-0.54 \mathrm{Ga})$ saw a rise in atmospheric oxygen to values not much less than $0.2 \mathrm{~atm}$. The shallow oceans followed suit, but the deep oceans were anoxic, at least during the intense Neoproterozoic ice ages. Atmospheric oxygen levels during stage 5 ( $0.54 \mathrm{Ga}$-present) probably rose to a maximum value of $c a 0.3$ atm during the Carboniferous before returning to its present value. The shallow oceans were oxygenated, while the oxygenation of the deep oceans fluctuated considerably, perhaps on rather geologically short time-scales.
\end{abstract}

Keywords: atmosphere; oceans; oxygen; mass-independent fractionation; great oxidation event; oceanic anoxic events

\section{INTRODUCTION}

The broad outlines of the oxygenation history of the atmosphere and oceans are now reasonably well known; but there are still significant lacunae in the record, especially for the oxygenation of the oceans, and many of the processes that were responsible for the major transitions in the oxidation state of the atmosphere-ocean system are still poorly defined. This paper attempts to summarize what is reasonably well established regarding the oxygenation of the atmosphere and oceans, to offer some suggestions regarding the state of the system during time periods when its oxygenation is still in dispute, and to propose mechanisms for the major oxygenation transitions. Some sections of the paper are rather speculative, perhaps more so than is warranted or desirable, but excusable because they are part of a scientific discussion meeting of the Royal Society, and therefore intended to encourage debate rather than simply to marshal the certainties of the field. The paper begins with the state of the ocean-atmosphere system during the deposition of the earliest known (meta)sediments. The boundaries of the succeeding stages of Earth history are defined by the times of significant change in the redox state of the system.

\section{STAGE 1: $3.85-2.45 \mathrm{Ga}$}

During the second half of the twentieth century evidence from several lines of investigation confirmed that the oxygen level in the atmosphere and oceans was

*holland@eps.harvard.edu

One contribution of 14 to a Discussion Meeting Issue 'Major steps in cell evolution'. very low during the Archaean and Early Palaeoproterozoic (see for instance Holland 1994). This conclusion was confirmed and extended by the discovery of large degrees of mass-independent fractionation (MIF) of the sulphur isotopes in sulphides and sulphates in pre$2.45 \mathrm{Gyr}$ sedimentary rocks. These measurements indicate that the $\mathrm{O}_{2}$ content of the Archaean atmosphere was generally less than $c a 10^{-5}$ present atmospheric level (PAL) (2 p.p.m.v.; Kasting et al. 2001; Pavlov \& Kasting 2002). At the time of writing, there is no defensible alternative to this interpretation of the pre-2.45 Gyr MIF-S signals. Figure 1 is a recent compilation of MIF-S data. Large MIF-S values are present in all time periods prior to $2.45 \mathrm{Gyr}$ ago $(\mathrm{Ga})$ except between $c a 2.8$ and $3.0 \mathrm{Ga}$. In this time interval, MIF-S values are small but non-zero (Watanabe et al. 2005). This may indicate that atmospheric $\mathrm{O}_{2}$ was present in quantities greater than $10^{-5}$ PAL between $c a$ 2.8 and $3.0 \mathrm{Ga}$, but elevated concentrations of other gases in the atmosphere may also have depressed the MIF-S signal during this period. If $\mathrm{O}_{2}$ was present in the atmosphere, its concentration was too low (less than $c a$ $\left.10^{-3} \mathrm{~atm}\right)$ to be registered by other, less-sensitive indicators of the level of atmospheric $\mathrm{O}_{2}$. The appearance of even small amounts of $\mathrm{O}_{2}$ in the atmosphere would have been accompanied by a large decrease in its $\mathrm{CH}_{4}$ content, and this decrease could have been responsible for the onset of the earliest known ice age at $2.9 \mathrm{Ga}$ (Young et al. 1998; Kasting \& Ono 2006). Although this connection is suggestive, it does not prove that $\mathrm{O}_{2}$ was present in the atmosphere at $2.9 \mathrm{Ga}$, because processes other than a decrease in $\mathrm{P}_{\mathrm{CH}_{4}}$ could have been responsible for the $2.9 \mathrm{Ga}$ ice age.

Not a great deal is known about the pre-3.0 Ga biosphere. Photosynthetic bacteria almost certainly 


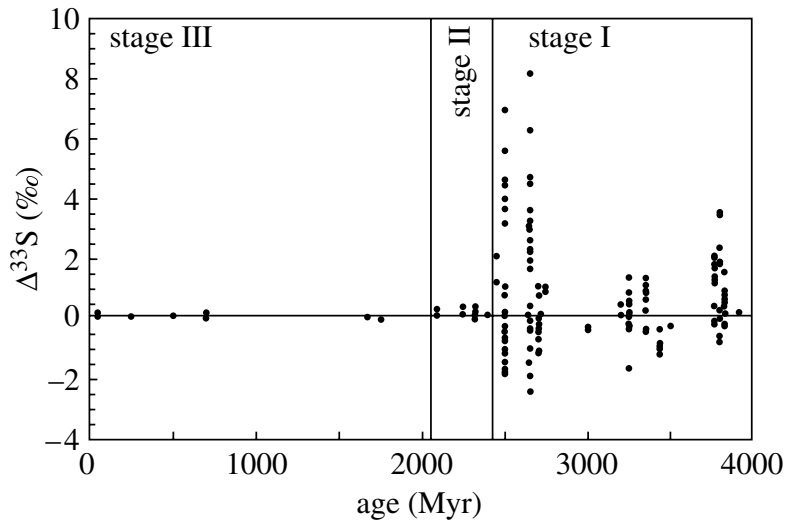

Figure 1. The values of $\Delta^{33} \mathrm{~S}$, indicator of mass-independent fractionation (MIF) of sulphur in pyrite and barite during the past $4000 \mathrm{Myr}$. The data were compiled by S. Ono from (Farquhar et al. 2000, 2002; Ono et al. 2003, Mojzsis et al. 2003; Hu et al. 2003).

employed photosystem-I (PS-I) and used $\mathrm{H}_{2}, \mathrm{H}_{2} \mathrm{~S}$ and/or $\mathrm{Fe}^{2+}$ to reduce $\mathrm{CO}_{2}$ to organic matter (Pierson 1994). The simplest explanation for the appearance of $\mathrm{O}_{2}$ in the atmosphere at concentrations in excess of $c a$ 2 p.p.m. at $c a 2.45 \mathrm{Ga}$ is that cyanobacteria using photosystem-II evolved at that time. However, this is unlikely. The presence of $2 \alpha$-methyl hopanes in sedimentary rocks more than $2.7 \mathrm{Gyr}$ suggests that cyanobacteria were important primary producers well before $2.45 \mathrm{Ga}$ (Brocks et al. 2003; Summons et al. 2006). Debate continues regarding the age of the oldest cyanobacteria (Schopf 1994, 2005; Brasier 2005), but it is likely that they were present at least $300 \mathrm{Myr}$ before the end of the large MIF-S signals.

Figure 2 shows a large compilation of data for the isotopic composition of carbon in limestones, dolomites and calcitic fossils (Shields \& Veizer 2002). Although there is a considerable amount of scatter in $\delta^{13} \mathrm{C}$ at any given time, the dataset as a whole can be divided into segments where the $\delta^{13} \mathrm{C}$ of marine carbonates was close to $0 \%$ o and segments where large excursions occur. During the first type of segment the atmosphere-ocean-crust system was apparently at or close to steady state. If, as seems likely, the $\delta^{13} \mathrm{C}$ value of $\mathrm{CO}_{2}$ injected into the atmosphere from mantle degassing has been close to $-5 \%$ o during much of Earth history, segments of time during which the $\delta^{13} \mathrm{C}$ value of marine carbonates was close to $0 \%$ were periods during which the deposition of organic matter drove the $\delta^{13} \mathrm{C}$ value of seawater to $c a 0 \%$. The $\delta^{13} \mathrm{C}$ of organic matter buried with sediments has been somewhat variable both in time and space. Hayes (1994) has shown that a good deal of Archaean organic matter had $\delta^{13} \mathrm{C}$ values between -30 and $-40 \%$. If organic matter and carbonate minerals were the only important sinks of volcanic and hydrothermal carbon, roughly $14 \%$ of the degassed carbon was converted to organic matter during the Archaean; the rest became part of carbonate sediments. These percentages are consistent with the removal of most or all of the volcanic $\mathrm{H}_{2}$ from the atmosphere via the overall reaction (Holland 2002)

$2 \mathrm{H}_{2}+\mathrm{CO}_{2} \rightarrow \mathrm{C}_{\text {org }}+2 \mathrm{H}_{2} \mathrm{O}$.

This result suggests that steady state during much, if not all, of the Archaean was achieved while the atmosphere contained no or essentially no $\mathrm{O}_{2}$. The $\mathrm{O}_{2}$ generated by cyanobacteria using photosystem-II was apparently insufficient to outweigh the reducing effect of $\mathrm{H}_{2}$ and other reductants on the atmosphereocean system.

The quantity of organic matter buried during any given period of Earth history has been the difference between the quantity of organic matter generated and the quantity of organic matter destroyed prior to burial. Today the quantity of organic matter that is buried is considerably less than $1 \%$ of the quantity of organic matter that is generated. It is likely that this percentage was somewhat larger during the Archaean, since oxygenic degradation of organic matter is so rapid; but the quantity of organic matter buried was almost certainly much smaller than the quantity that was generated. Then, as now, the role of the generation and the rate of destruction of organic matter both depended on the redox state of the atmosphere-ocean system. The rate of organic matter generation by PS-I organisms was probably limited by the availability of $\mathrm{H}_{2}, \mathrm{H}_{2} \mathrm{~S}$ and $\mathrm{Fe}^{2+}$ in the photic zone. The rate of generation of organic matter by cyanobacteria was probably limited by the quantity of nutrients remaining after their depletion by PS-I organisms. It seems likely that phosphate was usually limiting, since nitrogenfixing organisms existed, and denitrification was limited in a largely anoxic ocean. The destruction of organic matter was probably dominated by methanogenesis and $\mathrm{SO}_{4}{ }^{2-}$ reduction. In the absence of quantitative data for the rate of these processes during the Archaean, it seems premature to construct quantitative models to define the redox state of the atmosphere-ocean system. All that can be said with some assurance is that steady state during much, if not all of the Archaean was maintained without the enhancing effect of atmospheric $\mathrm{O}_{2}$ on the decomposition rate of organic matter.

The deeper oceans were almost certainly anoxic but not euxinic during the Archaean. This is indicated most clearly by the widespread occurrence of oxide facies banded iron formation (BIF; figure 3). The occurrence of large marine manganese deposits (figure 4 and table 1) during the Archaean almost certainly demands the presence of reducing conditions in the deeper oceans, where $\mathrm{Mn}^{2+}$ was able to accumulate, upwell into the shallow oceans, and be precipitated there as a constituent of Mn carbonates and/or Mn oxides (Roy 1997). Much of the shallow ocean was probably anoxic as well. However, there is some biomarker evidence for the presence of oxygen oases where the rate of oxygen production by cyanobacteria outweighed the downward mixing of reduced gases from the atmosphere.

There are no known Archaean phosphorite deposits (Cook \& Shergold 1986). Later erosion of such deposits cannot be ruled out, but their entire absence suggests that one or more of the ingredients that are required for the formation of phosphorites were missing during the Archaean. A likely candidate is too minor a downward transport of organic matter into the deeper oceans. Today $c a 10 \%$ of the organic matter that is generated in the photic zone sinks into the deeper oceans and is destroyed there, largely by oxygenic decomposition. The phosphate that is released during 


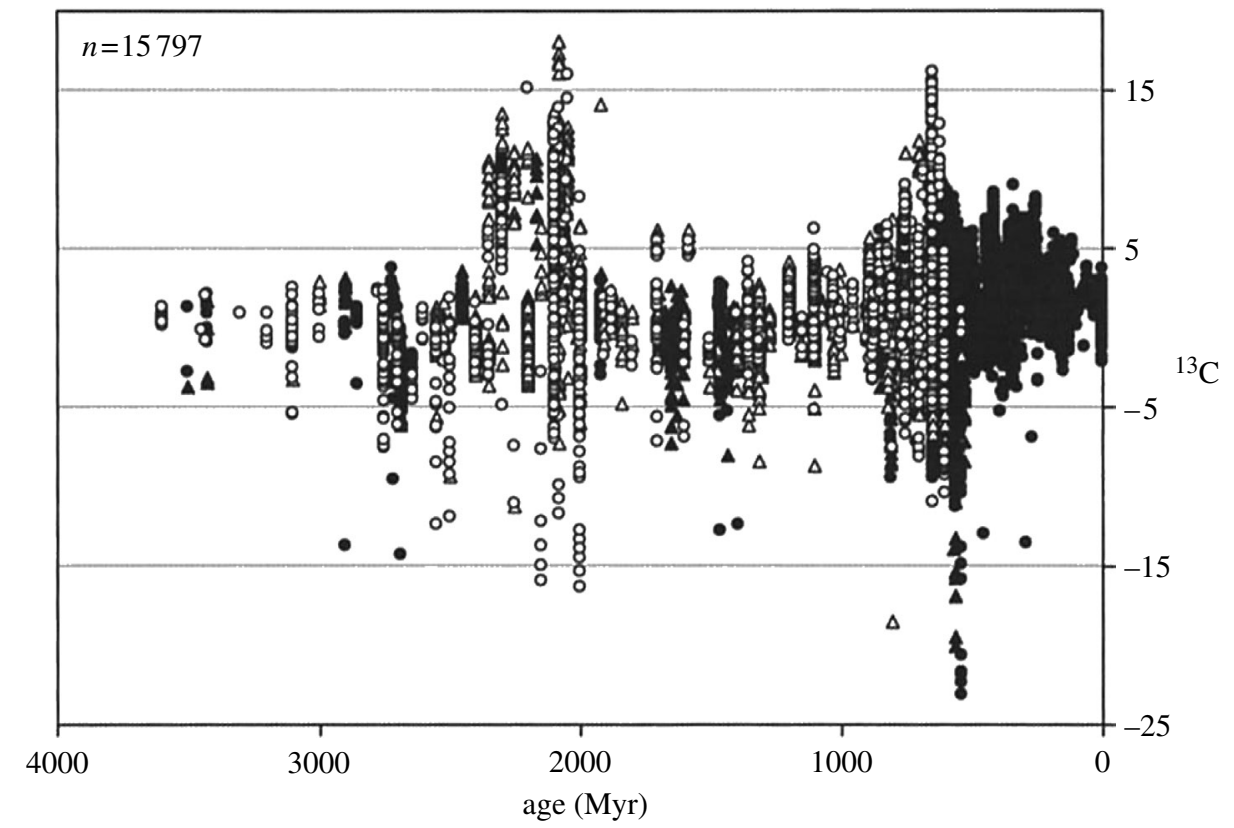

Figure 2. Carbon isotopic evolution of marine carbonate based on published analyses of limestones (circles), dolostones (triangles) and Phanerozoic calcitic fossils. Poorly time-constrained samples (more than $\pm 50 \mathrm{Ma}$ ) are shown as open symbols (Shields \& Veizer 2002).

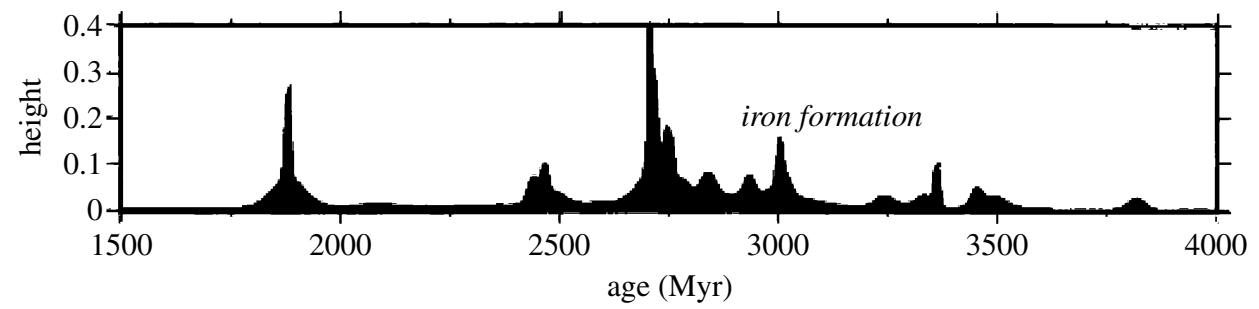

Figure 3. Time-series of occurrences of iron formation generated by summing Gaussian distributions of unit area in the compilation by Isley \& Abbott (1999).

this decomposition raises the phosphate concentration of deep ocean water. During upwelling this phosphateenriched seawater hosts intense biologic activity, which can give rise to the formation of phosphorites. Today much of the organic matter that sinks is packaged in faecal pellets which are ballasted by $\mathrm{CaCO}_{3}$ and $\mathrm{SiO}_{2}$. Such ballasting was very minor during the Archaean. Hence, the fraction of organic matter that sank into the deep ocean was almost certainly very much smaller than today (Logan et al. 1995). Adsorption of organic matter and dissolved phosphate on $\mathrm{Fe}(\mathrm{OH})_{3}$ generated in the near surface oceans by the effect of UVC on $\mathrm{Fe}^{2+}$ and by photosynthetic organisms which used $\mathrm{Fe}^{2+}$ as a reductant for $\mathrm{CO}_{2}$ must have transported some $\mathrm{PO}_{4}{ }^{3-}$ into the deep oceans, but apparently in quantities that were insufficient to generate phosphorite deposition.

\section{STAGE 2: $2.45-1.85 \mathrm{Ga}$}

The age of the youngest sediments in which sulphur has a large MIF signal is $2.41 \mathrm{Gyr}$ (see figure 1 ). Thereafter, the record is rather spotty until $2.32 \mathrm{Ga}$, when the pyrite of the Timeball Hill-Rooihogte Formations in South Africa was deposited. These contain no significant MIF-S signal (Bekker et al. 2004), and large MIF-S signals do not reappear thereafter. Atmospheric $\mathrm{O}_{2}$ seems to have appeared irreversibly between 2.41 and $2.32 \mathrm{Ga}$.
The reasons for the change in atmospheric chemistry during stage 2 have been debated widely but inconclusively (Canfield 2005). The near-coincidence of the end of Archaean BIF deposition and the appearance of atmospheric $\mathrm{O}_{2}$ is striking. The end of BIF deposition was followed by a ca 360 Myr hiatus before the resumption of major BIF deposition at $c a$ $2.08 \mathrm{Ga}$. Complete erosion of a BIF record between 2.44 and $2.08 \mathrm{Ga}$ is possible but unlikely. It is much more likely that $c a 2.45 \mathrm{Ga}$ a real change in the operation of the Earth system ushered in the oxygenated atmosphere (Barley et al. 2005). The decrease in the deposition rate of BIFs must have contributed to the change. Archaean BIFs contain on the average $c a$ $0.3 \times 10^{-2}$ mol P per mol Fe (Bjerrum \& Canfield 2002). The estimated minimum rate of $\mathrm{Fe}$ deposition in the very large Hamersley BIFs is ca $5 \times 10^{11} \mathrm{~mol} \mathrm{yr}^{-1}$ (Holland 1984). The total worldwide Fe output with BIFs during the deposition of the Hamersley BIFs was surely larger, but probably less than ca $3 \times$ $10^{12} \mathrm{~mol} \mathrm{yr}^{-1}$, which is ca 10 times the estimated present hydrothermal $\mathrm{Fe}^{2+}$ flux. The output of $\mathrm{P}$ with BIFs at that time was therefore probably more than $1.5 \times 10^{9} \mathrm{~mol} \mathrm{yr}^{-1}$ but less than $9 \times 10^{9} \mathrm{~mol} \mathrm{yr}^{-1}$. The most recent estimate of the input of $\mathrm{P}$ to the oceans today is ca $30 \times 10^{9} \mathrm{~mol} \mathrm{yr}^{-1}$ (Colman \& Holland 2000). The $P$ input during the Late Archaean was 


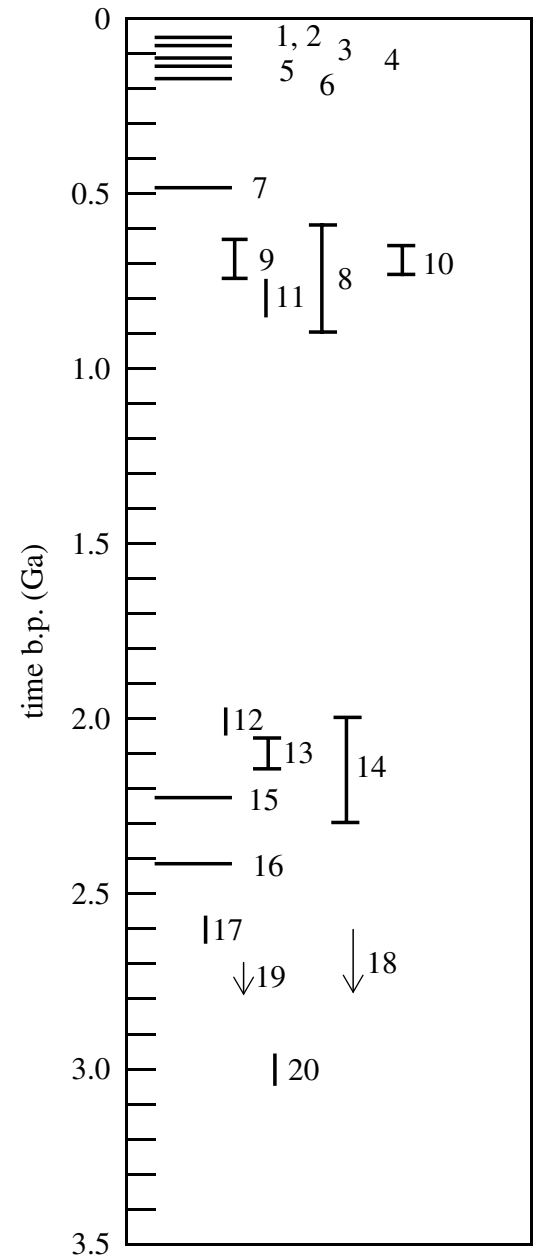

Figure 4. Marine manganese deposits (Roy 1997).

probably several times larger. A complete cessation of BIF formation could therefore have had a minor but possibly significant effect on the $\mathrm{P}$ budget of the oceans. More $\mathrm{P}$ would have become available for photosynthesis, and more organic matter could have been buried. It is not clear, however, whether the excess $\mathrm{O}_{2}$ generated in this way was sufficient to usher in the oxygenated atmosphere.

The precipitation of BIF consisting largely of $\mathrm{Fe}_{3} \mathrm{O}_{4}$ requires the oxidation of two-thirds of the parent $\mathrm{Fe}^{2+}$ to $\mathrm{Fe}^{3+}$ via the overall reaction

$6^{`} \mathrm{FeO}{ }^{\prime}+\mathrm{O}_{2} \rightarrow 2 \mathrm{Fe}_{3} \mathrm{O}_{4}$.

The oxidation of $5 \times 10^{11} \mathrm{~mol} \mathrm{Fe}^{2+} \mathrm{yr}^{-1}$ therefore requires $0.8 \times 10^{11} \mathrm{~mol} \mathrm{yr}^{-1} \mathrm{O}_{2}$. The oxidation of the likely maximum $\mathrm{Fe}^{2+}$ flux of $3 \times 10^{12} \mathrm{~mol} \mathrm{yr}^{-1}$ requires $5 \times 10^{11} \mathrm{~mol} \mathrm{O}_{2} \mathrm{yr}^{-1}$. This is trivial compared to the ca $4 \times 10^{14} \mathrm{~mol} \mathrm{O}_{2}$ generated annually today by marine photosynthesis, but it represents several percent of the $\mathrm{ca} 120 \times 10^{11} \mathrm{~mol}$ of $\mathrm{O}_{2}$ generated by the burial of organic matter (see for instance Holland 2002). The cessation of BIF deposition therefore reduced or eliminated a minor $\mathrm{O}_{2}$ sink and, in a small way, contributed to the transition of the atmosphere to an oxygenated state. However, other potentially important changes in the Earth's redox system, including a decrease in the hydrothermal flux of $\mathrm{H}_{2}$ and $\mathrm{H}_{2} \mathrm{~S}$, and changes in the biosphere and in the nutrient flux to the oceans could have been as or more important than these relatively minor shifts.

The period between 2.4 and $2.0 \mathrm{Ga}$ has become known as the Great Oxidation Event (GOE). The large positive excursion in the $\delta^{13} \mathrm{C}$ of marine carbonates between $c a 2.3$ and $2.0 \mathrm{Gyr}$ shows that during this period the carbon cycle was not in steady state (Karhu \& Holland 1996). Some of the excess carbon that was buried during this period raised the $\mathrm{O}_{2}$ content of the atmosphere, but most of the excess $\mathrm{O}_{2}$ was used to transform the geochemical cycle of $\mathrm{Fe}$ and of $\mathrm{S}$. In our study of the composition of Precambrian shales, the average $\mathrm{Fe}_{2} \mathrm{O}_{3}$ : $\mathrm{FeO}$ weight ratio of 190 pre- $2.3 \mathrm{Ga}$ shales was $c a 0.25$, and very few shales had $\mathrm{Fe}_{2} \mathrm{O}_{3} / \mathrm{FeO}$ weight ratios in excess of 1.0 (Bekker et al. 2003, see also Yamaguchi 2002). On the other hand, the average $\mathrm{Fe}_{2} \mathrm{O}_{3}$ : $\mathrm{FeO}$ weight ratio of $3172.3-2.1 \mathrm{Ga}$ shales in our dataset was 0.83 and some $25 \%$ of the shales had $\mathrm{Fe}_{2} \mathrm{O}_{3} / \mathrm{FeO}$ ratios in excess of 1.0 . This indicates a major change in the redox state of $\mathrm{Fe}$ during the course of the GOE.

The first evaporitic sediments known to contain gypsum or anhydrite were deposited during the GOE. (Melezhik et al. 2005). This indicates that the concentration of $\mathrm{SO}_{4}{ }^{2-}$ in seawater increased during the GOE, although $\mathrm{m}_{\mathrm{SO}_{4}{ }^{2-}}$ at $2.0 \mathrm{Ga}$ was almost certainly much less than today (Gellatly \& Lyons 2005). This is corroborated by the observation that the average $\delta^{34} S$ value of $S$ in pyrite remained close to $0 \%$ until near the end of the Proterozoic (figure 5), indicating that most of the $\mathrm{SO}_{4}{ }^{2-}$ input to the oceans continued to be removed as a constituent of pyrite until the Neoproterozoic. During the GOE, the surface oceans must have been mildly, but progressively more oxygenated. On the other hand, the formation of very large marine $\mathrm{Mn}$ deposits such as that of the Hotazel Formation in South Africa during the GOE indicates that the deep oceans continued to be anoxic

Marine phosphorite deposits made their first appearance during the GOE (Cook \& Shergold 1986, see table 2). If these deposits owed their origin to the same processes that were responsible for the formation of Phanerozoic phosphorites, the transport of phosphate into the deep oceans in the absence of ballasting of organic matter by $\mathrm{CaCO}_{3}$ and $\mathrm{SiO}_{2}$ must be explained. The most likely mechanism is the downward transport of $\mathrm{PO}_{4}{ }^{3-}$ adsorbed on $\mathrm{Fe}(\mathrm{OH})_{3}$. In the Black Sea today $\mathrm{Fe}^{2+}$ is oxidized to $\mathrm{Fe}^{3+}$ close to the $\mathrm{H}_{2} \mathrm{~S}-\mathrm{O}_{2}$ boundary. It is then precipitated as $\mathrm{Fe}(\mathrm{OH})_{3}$, sinks into the reduced, deeper part of the sea, and becomes reduced there. $\mathrm{PO}_{4}{ }^{3-}$ is adsorbed on the $\mathrm{Fe}(\mathrm{OH})_{3}$ precipitates and is released into the water column during the reduction of $\mathrm{Fe}(\mathrm{OH})_{3}$ below the chemocline (Shaffer 1986).

Although it is difficult to model the operation of this process quantitatively in the ocean during the GOE, it can be shown that it is a feasible mechanism for transporting significant quantities of $\mathrm{PO}_{4}{ }^{3-}$ into the deeper oceans. At the present rate of seawater hydrothermal fluxing some $3 \times 10^{11} \mathrm{~mol}$ of $\mathrm{Fe}^{2+}$ are added annually to the oceans at high-temperature vents. If this $\mathrm{Fe}^{2+}$ were mixed toward the surface oceans, oxidized to $\mathrm{Fe}^{3+}$, and precipitated as $\mathrm{Fe}(\mathrm{OH})_{3}$, 
Table 1. Marine manganese deposits (Roy 1997).

\begin{tabular}{|c|c|c|c|c|}
\hline & & age & geological sequence & deposits \\
\hline \multirow[t]{7}{*}{ Phanerozoic } & 1 & Early Oligocene & Early Kharkovian & Nikopol, Ukraine \\
\hline & 2 & & Early Kharkovian & Chiatura, Georgia \\
\hline & 3 & Late Cretaceous & & Imini-Tasdremt, Morocco \\
\hline & 4 & Middle Cretaceous & Mullaman beds & Groote Eylandt, Australia \\
\hline & 5 & Late Jurassic & Taman Fm, Chipoco facies & Molango, Mexico \\
\hline & 6 & Early Jurassic & & Urkut, Hungary \\
\hline & 7 & Middle Ordovician & Modaoxi & Taojiang, China \\
\hline \multirow{5}{*}{ Late Proterozoic } & 8 & $900-600 \mathrm{Ma}$ & Santa Cruz Fm, Jacadigo Group & Urucum, Brazil \\
\hline & 9 & ca 750-650 Ma & Chuos Fm, Damara Sequence & Otjosondu, Namibia \\
\hline & 10 & ca $720-680 \mathrm{Ma}$ & Datangpo Sequence, Nantuo ice age & $\begin{array}{l}\text { Xiangtan, Minle, Datangpo, } \\
\text { Tangganshan, China }\end{array}$ \\
\hline & 11 & ca $800 \mathrm{Ma}$ & Penganga Group & Tamsi, Guda, Kanpa, India \\
\hline & 12 & ca $2.0 \mathrm{Ga}$ & Sausar Group & $\begin{array}{l}\text { Mansar, Chikla, Tirodi, } \\
\text { India }\end{array}$ \\
\hline \multirow[t]{5}{*}{ Early Proterozoic } & 13 & ca $2.1 \mathrm{Ga}$ & Francevillian Series & $\begin{array}{l}\text { Okouma and Bangombe } \\
\text { Plateaus, Gabon }\end{array}$ \\
\hline & 14 & ca $2.3-2.0 \mathrm{Ga}$ & Birimian Supergroup & $\begin{array}{l}\text { Nsuta, Ghana; Mokta, Ivory } \\
\text { Coast; Tambao, Burkina } \\
\text { Faso }\end{array}$ \\
\hline & 15 & ca $2.24 \mathrm{Ga}$ & $\begin{array}{l}\text { Hotazel Fm Postmasburg Group } \\
\text { Transvaal Supergroup }\end{array}$ & $\begin{array}{l}\text { Mamatwan, Wessels, South } \\
\text { Africa }\end{array}$ \\
\hline & 16 & 2.42 & Koegas & South Africa \\
\hline & 17 & ca $2.6 \mathrm{Ga}$ & Chitradurga Group & $\begin{array}{l}\text { Chitradurga-Tumkur Kum- } \\
\text { si-Hornhalli, Karnataka, } \\
\text { India }\end{array}$ \\
\hline \multirow[t]{3}{*}{ Archaean } & 18 & $c a>2.6 \mathrm{Ga}$ & Eastern Ghats Sequence & $\begin{array}{l}\text { Kodur, Garividi, Garbham, } \\
\text { Andhra Pradesh, India }\end{array}$ \\
\hline & 19 & $c a>2.7 \mathrm{Ga}$ & Rio das Velhas Supergroup & $\begin{array}{l}\text { Morro do Mina, Minas } \\
\text { Gerais, Brazil }\end{array}$ \\
\hline & 20 & ca $3.0 \mathrm{Ga}$ & Iron Ore Group & $\begin{array}{l}\text { Joda, Kalimati, Gurda Pha- } \\
\text { gua, Mahulsukha, Orissa, } \\
\text { India }\end{array}$ \\
\hline
\end{tabular}

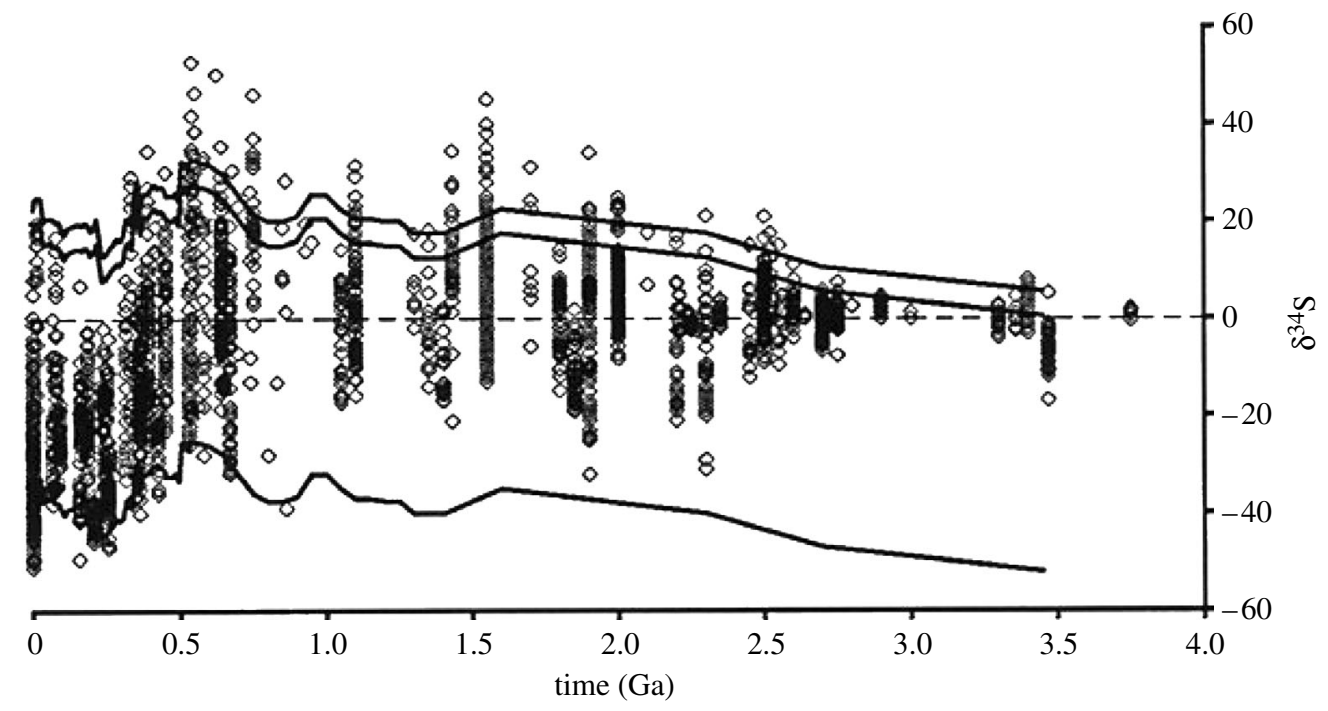

Figure 5. Compilation of the isotopic composition of sedimentary sulphides (diamonds) through time. Also shown is a reconstruction of the isotopic composition of sulphate (upper line) and, as a guide, the isotopic composition of sulphate offset by $55 \%$ (lower line) (Canfield 2005).

the $\mathrm{P}:$ Fe mol ratio of the precipitate would have been

$\frac{\mathrm{P}}{\mathrm{Fe}} \sim 0.018+0.060 \mathrm{~m}_{\mathrm{PO}_{4}^{3-}}$,

where $\mathrm{m}_{\mathrm{PO}_{4}^{3-}}$ is the total $\mathrm{P}$ concentration in $\mu \mathrm{mol}^{-1}$ in the local seawater (Wheat et al. 1996; Feely et al. 1998). The $\mathrm{PO}_{4}^{3-}$ concentration of surface seawater was probably very low, but increased toward the base of the photic zone. $\mathrm{Fe}(\mathrm{OH})_{3}$ precipitation probably occurred near the chemocline, where $\mathrm{m}_{\mathrm{PO}_{4}^{3-}}$ was probably in the $\mu$ mol range. The $\mathrm{P}: \mathrm{Fe}$ ratio in the sinking $\mathrm{Fe}(\mathrm{OH})_{3}$ may therefore have been between $c a 0.08$ and 0.14 . A single pass of all hydrothermal $\mathrm{Fe}^{2+}$ would then have removed between $0.2 \times 10^{11}$ and $0.4 \times 10^{11} \mathrm{~mol} \mathrm{PO}_{4}^{3-}$ 
Table 2. Palaeoproterozoic phosphorites (Nothold \& Sheldon 1986).

\begin{tabular}{ll} 
North America & $\begin{array}{l}\text { Marquette Range Supergroup } \\
\text { Animikie Group }\end{array}$ \\
Europe & Lower Proterozoic Schist belt, Finland \\
Korea & Mach' onnyang Series \\
China & Dongjian Group \\
India & Bijawar Group \\
Australia & Pine Creek Geosyncline, Rum Jungle \\
& District, Northern Territory \\
\hline
\end{tabular}

from the surface into the deep ocean. This accounts for $3-6 \%$ of the estimated present day $\mathrm{PO}_{4}{ }^{3-}$ flux into the oceans. Larger quantities of $\mathrm{PO}_{4}{ }^{3-}$ could have been moved into the deeper oceans if the hydrothermal $\mathrm{Fe}^{2+}$ made several redox passes through the surface oceans.

The present day oceans are ventilated at a rate of ca. $1 \times 10^{18} \mathrm{~kg} \mathrm{yr}^{-1}$. If the $\mathrm{PO}_{4}{ }^{3-}$ absorbed on $\mathrm{Fe}(\mathrm{OH})_{3}$ was released at depth and was added to the $\mathrm{PO}_{4}{ }^{3-}$ which was carried downward with surface waters cycled along the Proterozoic analogue of the modern conveyor belt, the increment of $\mathrm{PO}_{4}{ }^{3-}$ would have been between 0.02 and $0.04 \mu \mathrm{mol} \mathrm{kg}^{-1}$. This is too small to affect the formation phosphorites. It is likely, however, that the hydrothermal input of $\mathrm{Fe}^{2+}$ during the GOE was several times greater than the present rate, and iron could well have cycled several times across the chemocline. If so, the $\mathrm{PO}_{4}{ }^{3-}$ concentration of seawater could have been augmented by as much as $0.5 \mu \mathrm{mol}^{-1}$ in its passage along the conveyor belt. An increment of this magnitude could have played a significant role in promoting the formation of the Palaeoproterozoic phosphorites.

The level of atmospheric $\mathrm{O}_{2}$ during the GOE is still rather uncertain. The mineralogy and chemical composition of the Hekpoort paleosol profile at Gaborone, Botswana, suggests that at $2.25 \mathrm{Ga}$ atmospheric $P_{\mathrm{O}_{2}}$ was between $c a 0.1$ and 5\% PAL (Yang \& Holland 2003). A 2.2-1.9 Ga palaeoweathering profile in Griqualand West, South Africa, suggests that during the formation of this profile $P_{\mathrm{O}_{2}}$ was greater than ca $15 \%$ PAL. These estimates are, perforce, rough; they are consistent with the notion that $P_{\mathrm{O}_{2}}$ was much greater at the end than at the beginning of the GOE, but that at $2.0 \mathrm{Ga} P_{\mathrm{O}_{2}}$ was still significantly lower than the present level of 0.21 atm.

The deposition of BIF's resumed ca $2.08 \mathrm{Ga}$ and continued until $1.8 \mathrm{Ga}$ (Isley \& Abbott 1999). Then it apparently ceased for a billion years, ushering in the long period of environmental stability that has been called the 'boring billion'.

\section{STAGE 3: 1.85-0.85 Ga}

Some two decades ago, I ascribed the end of BIF deposition at $c a 1.8 \mathrm{Ga}$ to the oxidation of the deep oceans (Holland 1984). Since then Canfield (1998) has suggested that the end of BIF deposition was due to just the opposite process: the development of sulphidic deep oceans. This model of the Mesoproterozoic oceans has become known as the 'Canfield Ocean'. Canfield (1998) pointed out that the supply of $\mathrm{O}_{2}$ to the deep oceans during this period was almost certainly much less than it is today, if-as seems likely-the $\mathrm{O}_{2}$ content of the atmosphere was $10-20 \%$ PAL. The $\mathrm{O}_{2}$ content of seawater would then have become exhausted during its passage from the sea surface downward and along the oceanic conveyor belt. The deep ocean would therefore have become anoxic or euxinic, if all other parameters of the system had remained unchanged. The two most important of these parameters are the annual rate at which organic matter sinks into the deep oceans and the rate at which surface water sinks into the deep oceans. As pointed out earlier in this paper, the flux of sinking organic matter was probably much less during the Mesoproterozoic than today. At present the concentration of $\mathrm{O}_{2}$ in North Atlantic deep water is ca $260 \mu \mathrm{m}$. Some $120 \mu \mathrm{m}$ of this are lost during transit along the conveyor belt (Broecker \& Peng 1982), largely due to the oxidation of sinking organic matter. Recent work by Francois et al. (2002), Klaas and Archer (2002), and Armstrong et al. (2002) has shown that today very little, if any, organic matter sinking from the photic zone reaches depths greater than $2000 \mathrm{~m}$ in the absence of ballasting by $\mathrm{CaCO}_{3}$. As far as is known, $\mathrm{CaCO}_{3}$ ballasting did not exist during the Mesoproterozoic. The fraction of organic matter reaching the deep oceans during this period must, therefore, have been much smaller than today. If the quantity of organic matter sinking annually into the deep oceans during the Mesoproterozoic was only onetenth of the present quantity (J. M. Hayes 2005, personal estimate) the loss of $\mathrm{O}_{2}$ during passage through the deep oceans would have been only $c a$ $12 \mu \mathrm{mol}^{-1}$, all other things being equal. Such a loss would not have been sufficient to eliminate all of the $\mathrm{O}_{2}$ from sinking surface water at the present rate of ocean ventilation, even if the atmospheric $\mathrm{O}_{2}$ level was only $10 \%$ PAL. This calculation does not prove that the deep Mesoproterozoic oceans were mildly oxygenated, only that anoxic or euxinic deep oceans during this period were not inevitable.

The absence of marine manganese deposits during the entire 'boring billion' (figure 4) suggests that the deep oceans were indeed mildly oxygenated between 1.8 and $0.8 \mathrm{Ga}$. It is possible that all of the marine manganese deposits from this period have been eroded or are still covered, but this seems unlikely. Their absence from the Mesoproterozoic record extends over a billion years, whereas they are present in the geologic record both before 1.8 and after $0.8 \mathrm{Ga}$.

The reason for the existence of mildly oxygenated deep oceans may well be a very small delivery rate of organic matter to the deep oceans between 1.8 and $0.8 \mathrm{Ga}$. The strongest evidence for this is the absence of phosphorites during this entire period. In the absence of significant ballasting, the transfer of organic matter and its contained $\mathrm{PO}_{4}^{3-}$ into the deep oceans must have been very minor. In addition, $\mathrm{Fe}^{2+}$ from hydrothermal vents would have been oxidized to $\mathrm{Fe}^{3+}$ and precipitated as a constituent of $\mathrm{Fe}(\mathrm{OH})_{3}$ in the deep oceans, and would not have been available to transport $\mathrm{PO}_{4}{ }^{3-}$ downward from the surface ocean during stage 2 , as proposed above. The beds of haematitic jasper proximal and distal to the $1.74 \mathrm{Ga}$ volcanogenic massive sulphide (VMS) deposits at Jerome, AZ, are one example of this process (Slack et al. 2005). Some of the jaspers contain haematitic 
filaments $1-3 \mu \mathrm{m}$ in diameter and $30-50 \mu \mathrm{m}$ long that are morphologically similar to remains of $\mathrm{Fe}^{2+}$. oxidizing bacteria in Ordovician and younger VMSrelated jaspers. The rare earth element (REE) patterns of the jaspers contain no or small positive $\mathrm{Ce}$ anomalies. Another example is supplied by the $1-2 \mathrm{~m}$ thick bands of magnetite and/or haematite in the metamorphosed ca $1.2 \mathrm{Gyr}$ Gamsberg VMS zinc deposit in the Namaqualand district of the northwestern Cape Province, South Africa (Rozendaal \& Stumpfl 1984).

Organic matter generated in the photic zone was nearly completely recycled in the shallow oceans. Where the $\mathrm{O}_{2}$ minimum zone intersected the sediment-water interface, euxinic areas such as the McArthur Basin in Australia tended to develop (Shen et al. 2002). The isotopic composition of Mo in the sediments of these basins indicates that they were major sinks for this element. Deposition of $\mathrm{Mo}^{6+}$ with manganese nodules was apparently less extensive than now (Anbar \& Knoll 2002; Arnold et al. 2004). It is not clear whether this was due to the lower $\mathrm{O}_{2}$ content of deep ocean waters or to the more widespread removal of Mo in shallow euxinic basins, or to both.

This brings us back to the reasons for the cessation of BIF deposition at $c a 1.8 \mathrm{Ga}$. It seems unlikely that the development of a 'Canfield Ocean' was responsible for their absence in sediments between 1.8 and 0.8 Gyr. The end of BIF deposition may well have been related to a decrease in the flux of $\mathrm{Fe}^{2+}$ to the oceans, the subsequent elimination of nearly all $\mathrm{Fe}^{2+}$ from the oceans, and the beginning of a non-stratified, mildly oxidized ocean. Although this seems likely, other processes may also have contributed to create a higher oceanic oxidation state. Such an increase may then have been responsible for the oxidation of $\mathrm{Fe}^{2+}$, the precipitation of $\mathrm{Fe}(\mathrm{OH})_{3}$ in the deep oceans, and the lack of BIF deposition between 1.8 and $0.8 \mathrm{Ga}$.

\section{STAGE 4: $0.85-0.54 \mathrm{Ga}$}

If it is apt to describe stage 3 as boring, then stage 4 was blustery and baleful. Three, perhaps the largest three ice ages, visited the Earth (Hoffman \& Schrag 2002; Hoffman in press), and these may all have been followed by unusually hot climates. On the other hand, the period can also be described as burgeoning and blossoming. Evolution proceeded apace and culminated in the appearance of animals and the biological explosion near the Cambrian-Precambrian boundary (Knoll 2005, Conway Morris 2005). The second of the major positive $\delta^{13} \mathrm{C}$ excursions of marine carbonates occurred during this period (figures 2 and 6). This signalled the burial of excess carbon and the generation of excess $\mathrm{O}_{2}$. The $\mathrm{O}_{2}$ content of the atmosphere (Berner 2004) and the sulphate concentration of seawater (Horita et al. 2002) rose to levels that were probably not much lower than those of the present day (Canfield 2005). The sediments of the last $300 \mathrm{Myr}$ of the Proterozoic contain BIFs, marine manganese deposits and evaporites. The BIFs are widespread (figure 7) and are associated with glacial deposits (Hoffman in press). Three of the four major groups of manganese deposits are also associated with

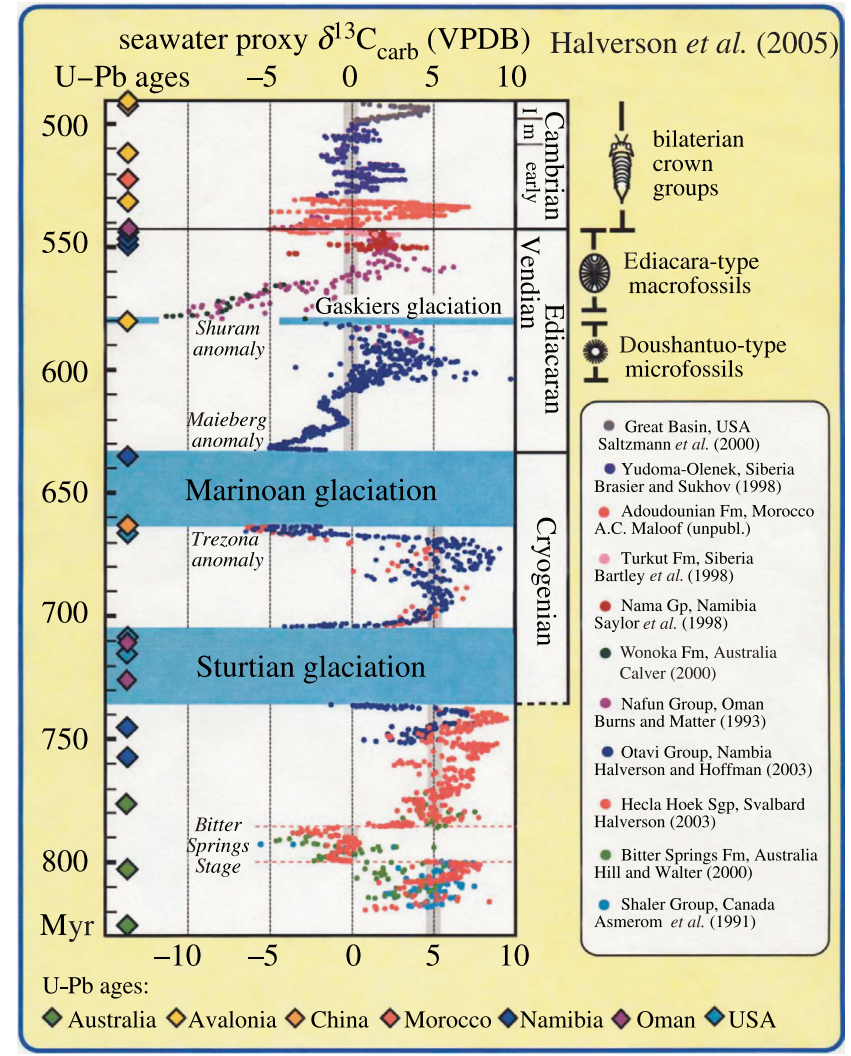

Figure 6. The isotopic composition of carbon in marine carbonates between 490 and $830 \mathrm{Ma}$ (Halverson et al. 2005).
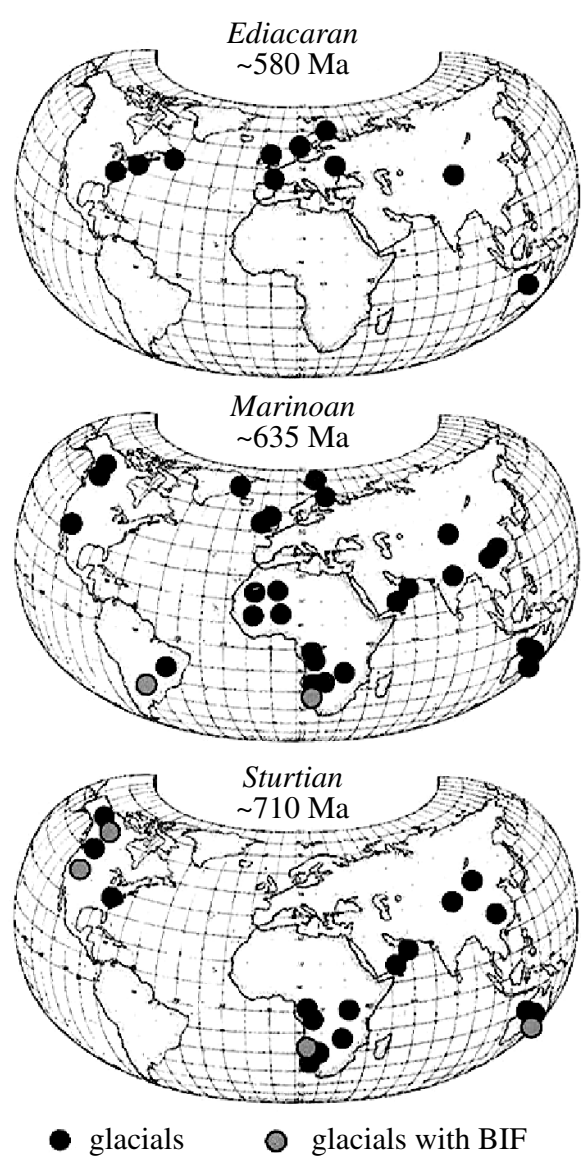

(Raisz 'armadillo' projection)

Figure 7. The distribution of Neoproterozoic glacial deposits with and without BIFs (Hoffman in press). 


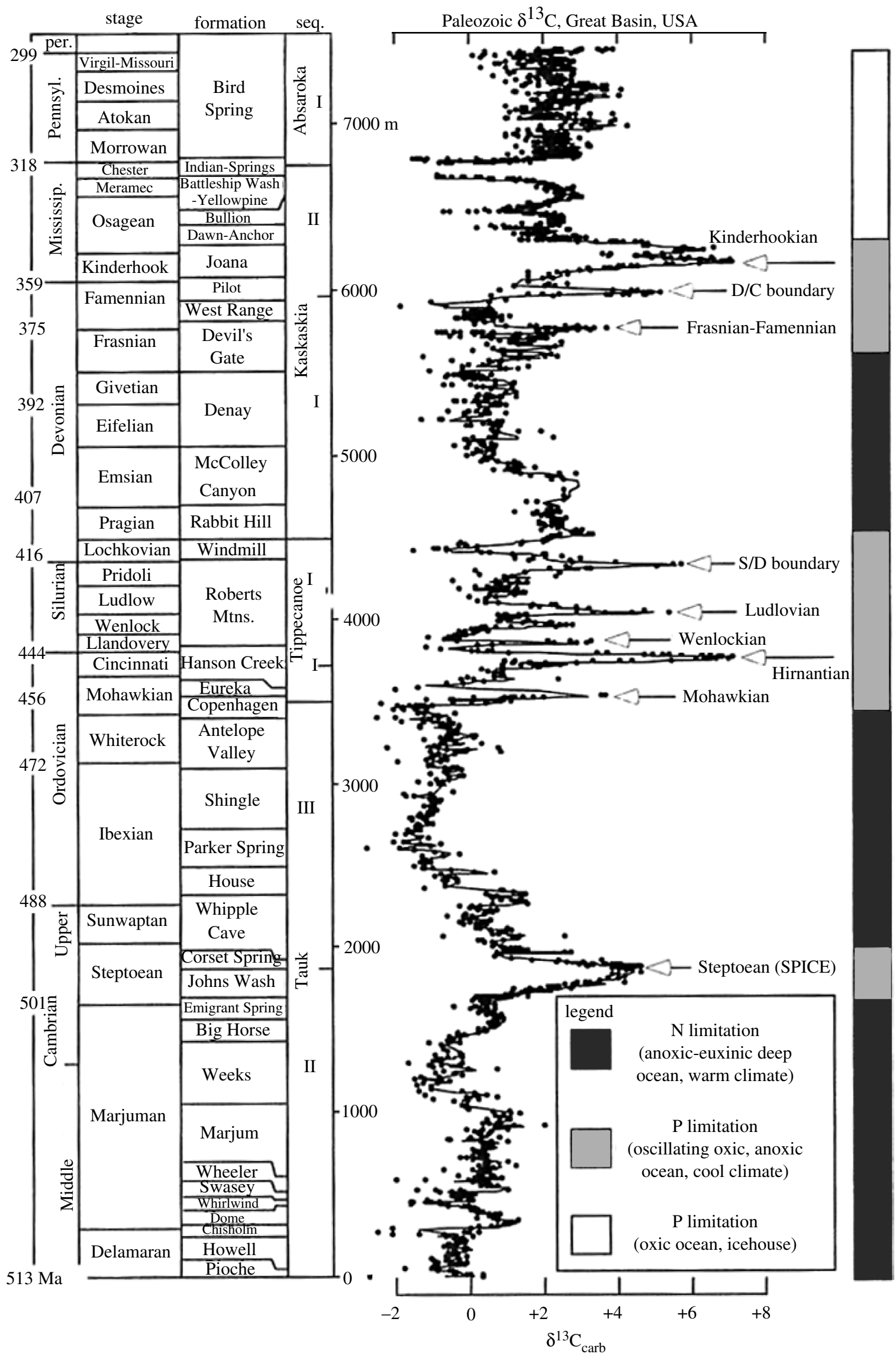

Figure 8. Composite diagram of the $\delta^{13} \mathrm{C}$ value of Palaeozoic carbonates of the Great Basin, USA (Saltzman 2005).

glacial deposits. Those of the Penganga Group in India are not (Roy 1997).

The Neoproterozoic is one of the most phosphorite rich periods in Earth history. Its sediments host some of the worlds largest phosphorite deposits (Cook \& Shergold 1986). The return of phosphorite deposition after a billion year hiatus is almost certainly due to the increased diversity of acritarchs and other protistan 


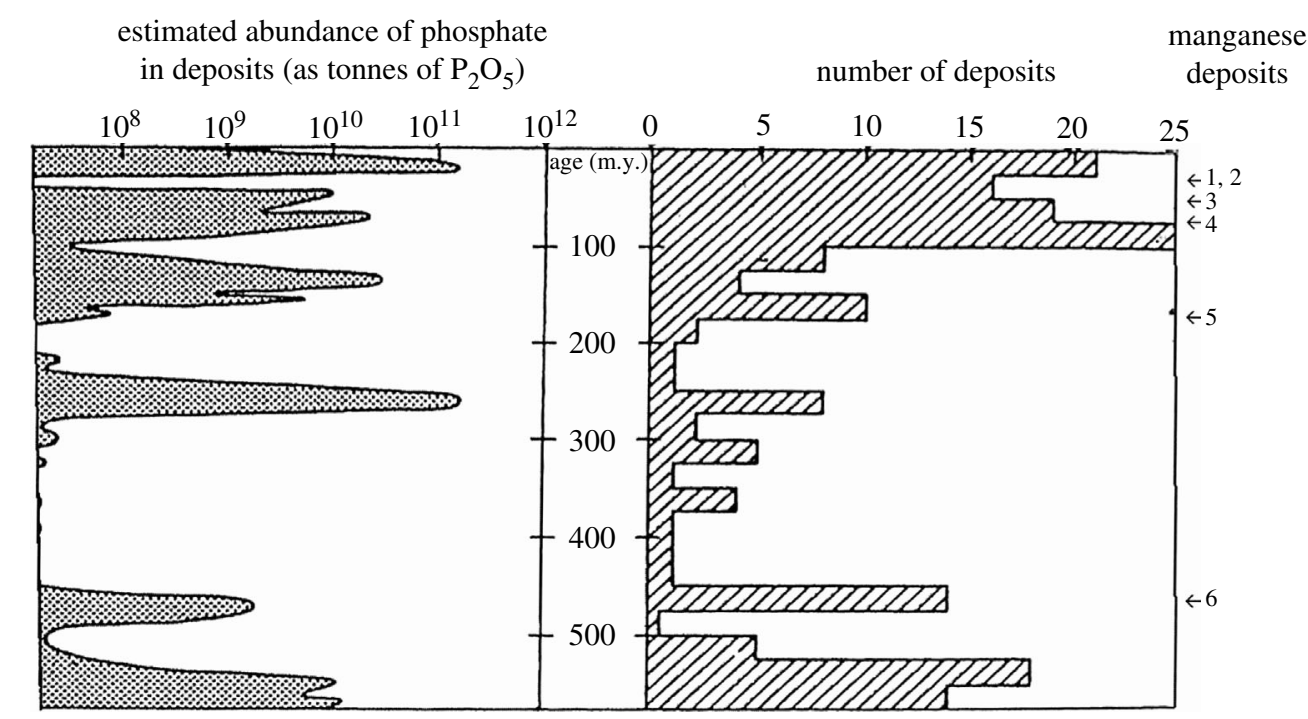

Figure 9. Estimated abundance of phosphate (expressed as metric tons $\mathrm{P}_{2} \mathrm{O}_{5}$ ) in phosphate deposits throughout the Phanerozoic. The fixed time interval in the histogram is $25 \mathrm{Myr}$. It should be noted that a logarithmic scale is used for $\mathrm{P}_{2} \mathrm{O}_{5}$ abundance (Cook \& McElhinny 1979). At the right margin, there is a list of the large Phanerozoic marine manganese deposits (Roy 1997). The numbers identify the following deposits: 1, Nikopol, Ukraine; 2, Chiatura, Georgia; 3, Groote Eylandt, Australia; 4, Molango, Mexico; 5, Úrkút, Hungary; 6, Taojiang, China.

morphotypes (e.g. Butterfield \& Rainbird 1998), whose remains sank into the deep ocean. The transport of organic matter into the deep oceans was also augmented by the development of organisms such as the vase-shaped microfossils (VSM) with tests consisting of 1 to more than $10 \mu \mathrm{m}$ silica scales (Porter \& Knoll 2000; Porter et al. 2003). The increased downward transport of organic matter with and without ballast was apparently sufficient to return anoxic condition to the deep oceans for at least parts of stage 4. The close association of BIFs and many of the manganese deposits with glacial deposits is striking. Anoxia may have been particularly pronounced during the three major Neoproterozoic glacial periods. The circulation of deep water during these periods may have been particularly intense, and this may have contributed to the close temporal association of BIFs and manganese deposits with the three ice ages.

\section{STAGE 5: THE LAST $0.54 \mathrm{Gyr}$}

The level of atmospheric $\mathrm{O}_{2}$ has probably varied significantly during the Phanerozoic. Improvements in computation schemes from BLAG to SUPERBLAG to GEOCARB to BROD have increased the believability of the results, but additional direct confirmation of the calculated $\mathrm{O}_{2}$ levels is still needed. The most recent computations (Berner 2004) indicate that atmospheric $\mathrm{O}_{2}$ may have attained values as high as $0.35 \mathrm{~atm}$ during the Permo-Carboniferous (figure 10). This result agrees with the isotopic composition of Permo-Carboniferous fossil plants, the effect of $\mathrm{O}_{2}$ on photosynthetic carbon isotope fractionation during plant growth, and the development of giant insects during this period of Earth history (Graham et al. 1995; Dudley 1998; Lane 2002). The principal cause of the proposed high $\mathrm{O}_{2}$ levels was probably the evolution of the large vascular land plants that brought about increased $\mathrm{O}_{2}$ production and increased $\mathrm{O}_{2}$ levels due to the enhanced global burial of microbially resistant, lignin-rich organic matter during the Permo-Carboniferous (Berner 2004). The surface oceans must have been oxygenated throughout the Phanerozoic, but the oxidation state of the deeper oceans has fluctuated widely. The Cretaceous oceanic anoxic events (OAEs) are particularly well documented (Arthur et al. 1985). They coincided with rising sea level and warm, generally stably stratified oceans. The mechanisms that induced widespread deposition of organic carbonrich sediments involved some combination of elevated biologic productivity and enhanced organic carbon preservation under oxygen-depleted water masses (Arthur 2005).

As shown in figure 8 , the $\delta^{13} \mathrm{C}$ data for Palaeozoic carbonates of the Great Basin, USA is extremely 'spikey' (Saltzman 2005), suggesting that between 299 and $513 \mathrm{Myr}$ ago (Ma) the rate of organic carbon burial varied rapidly in this part of the oceans and possibly in the world ocean. Phosphorites are common in the Phanerozoic, but some periods within this era are much richer in phosphorites than others, as shown in figure 9. The correlation between the timing of large phosphorites and manganese deposits is not striking; neither is the correlation between the timing of the large OAEs and that of the large manganese deposits. The Cretaceous anoxic event OAE 1 peaked near the Albian-Aptian boundary, ca $115 \mathrm{Ma}$, whereas the Groote Eylandt giant manganese deposit formed close to $100 \mathrm{Ma}$ in the Late Albian to Early Cenomanian. On the other hand, OAE 2 and the IminiTasdremi manganese deposits both occurred ca $93 \mathrm{Ma}$, close to the Cenomanian-Turonian boundary. The lower Oligocene manganese deposits at Nikopol in the Ukraine and at Chiatura in Georgia were deposited during what was no more than a mild positive $\delta^{13} \mathrm{C}$ carbonate excursion at $35 \mathrm{Ma}$ (Miller \& Fairbanks 1985). These deposits seem to be related to local or regional rather than to oceanic periods of oxygen depletion (Frakes \& Bolton 1992). The limited correlation between the occurrence of OAEs, 

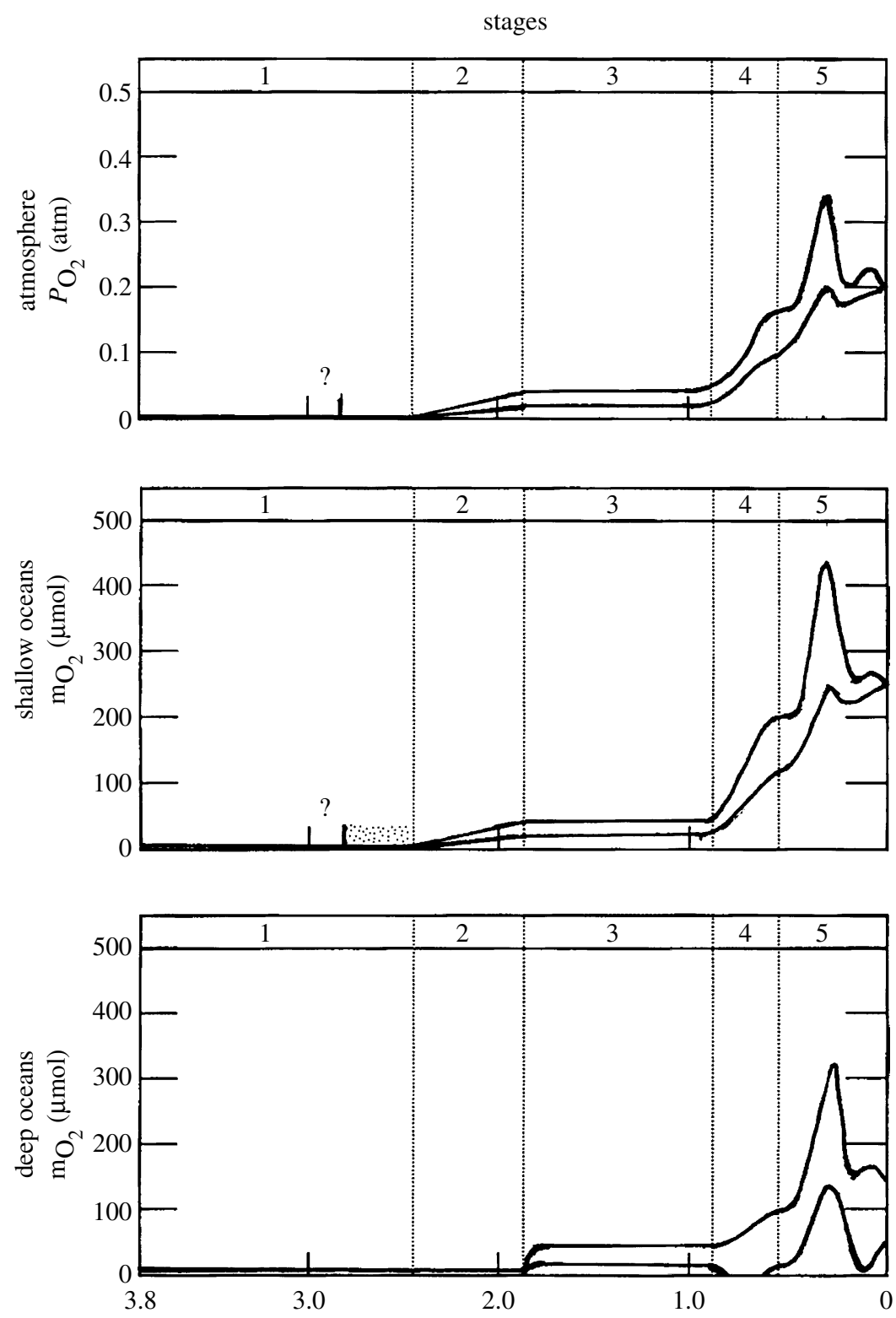

Figure 10. Estimated evolution of atmospheric $P_{\mathrm{O}_{2}}$ and the concentration of $\mathrm{O}_{2}$ in the shallow and deep oceans.

phosphorites and marine manganese deposits surely reflects the complexity of their development and the incomplete overlap between the factors that control their formation (Roy 1992, 1997).

\section{SUMMARY AND CONCLUSIONS}

Figure 10 summarizes the proposed evolution of the atmospheric pressure of $\mathrm{O}_{2}$ and the concentration of $\mathrm{O}_{2}$ in the shallow and deep oceans during the last 3.8 Gyr of Earth history. During stage 1, from 3.85 to $2.45 \mathrm{Ga}$, atmospheric $\mathrm{O}_{2}$ was almost certainly less than a few parts per million, except possibly during the period between 3.0 and $2.8 \mathrm{Ga}$. The oceans were almost certainly anoxic except perhaps in oxygen oases within the photic zone. Such oases may have been present during the last 200-300 Ma of the Archaean. They probably existed earlier if cyanobacteria evolved before $2.8 \mathrm{Ga}$. The deep oceans were almost certainly anoxic during all of stage 1 .

Atmospheric $\mathrm{O}_{2}$ rose during the GOE between $c a$ 2.4 and $2.0 \mathrm{Ga}$. Its value at $2.0 \mathrm{Ga}$ is still poorly defined. It was probably higher than $10 \%$ PAL
(0.02 atm) but significantly lower than 1 PAL $(0.2 \mathrm{~atm})$. The concentration of $\mathrm{O}_{2}$ in much of the shallow oceans was probably close to equilibrium with atmospheric $\mathrm{O}_{2}$ levels, but the deep oceans were almost certainly anoxic during much, if not all of stage 2 (2.45-1.85 Ga).

Stage $3(1.85-0.85 \mathrm{Ga})$ seems to have been rather static. There is no evidence for large changes in the $\mathrm{O}_{2}$ content of the atmosphere or in the shallow oceans. In some areas, the $\mathrm{O}_{2}$ minimum zone must, however, have been anoxic or euxinic as indicated, for instance, by the highly reduced $c a 1.5$ Gyr sediments of the McArthur Basin, Australia (Shen et al. 2002). Such spatial heterogeneities in the $\mathrm{O}_{2}$ content of the shallow ocean are not represented in figure 10. The deep oceans appear to have been mildly oxygenated during much, if not all of stage 3 .

Stage $4(0.85-0.54 \mathrm{Ga})$ saw a further rise in the level of atmospheric $\mathrm{O}_{2}$ and in the concentration of $\mathrm{O}_{2}$ in the shallow oceans. However, anoxic and euxinic conditions prevailed in the shallow oceans at least locally, as on the Yangtze Platform at the end of the 
Neoproterozoic (Mao et al. 2002). Deep ocean water may have been anoxic during most of this stage.

During stage 5 (the last $0.54 \mathrm{Gyr}$ ) the level of atmospheric $\mathrm{O}_{2}$ may have passed through a maximum during the Carboniferous before returning to $0.2 \mathrm{~atm}$, perhaps along a rather irregular path. Shallow ocean water probably followed the same pattern. Deep ocean water apparently had a rather complex history, which included low- $\mathrm{O}_{2}$ periods such as those during the Cretaceous OAEs. Figure 10 is probably an improvement over previous attempts to represent the oxygenation of the atmosphere and oceans, but it is no more than a step along the long road ahead. The pattern proposed for the oxygenation of the atmosphere and oceans is probably qualitatively correct, but its quantitative aspects should be regarded with a significant degree of scepticism.

This paper owes a great deal to discussions with a very large number of colleagues. Ariel Anbar, Andrey Bekker, Donald Canfield, John Hayes, James Kasting, Andrew Knoll and Shuhei Ono have been among the most deeply involved, and I owe them a particularly great debt of gratitude. Lee Kump and Harald Strauss are thanked for helpful reviews of the manuscript. Partial support during the writing of this paper was supplied by NSF grant EAR-0309258, to Harvard University. Travel funds were kindly made available by the Royal Society.

\section{REFERENCES}

Anbar, A. D. \& Knoll, A. H. 2002 Proterozoic ocean chemistry and evolution: a bioinorganic bridge? Science 297, 1137-1142. (doi:10.1126/science.1069651)

Armstrong, R. A., Lee, C., Hedges, J. L., Honjo, S. \& Wakeham, S. G. 2002 A new, mechanistic model for organic carbon fluxes in the ocean based on the quantitative association of POC with ballast minerals. Deep-Sea Res. II, 49, 219-236.

Arnold, G. L., Anbar, A. D., Barling, J. \& Lyons, T. W. 2004 Molybdenum isotope evidence for widespread anoxia in mid-Proterozoic oceans. Science 304, 87-90. (doi:10. 1126/science.1091785)

Arthur, M. A. 2005 Oceanic anoxic events: carbon and nitrogen isotope signatures and their implications. Earth System Processes 2, abstract with programs, 50.

Arthur, M. A., Dean, W. E. \& Schlanger, S. O. 1985 Variations in the global carbon cycle during the Cretaceous related to climate, volcanism, and changes in atmospheric $\mathrm{CO}_{2}$. In The carbon cycle and atmospheric $\mathrm{CO}_{2}$ : natural variations Archean to present (ed. E. T. Sundquist \& W. S. Broecker), pp. 504-529. Washington, DC: American Geophysical Union.

Barley, M. E., Bekker, A. \& Krapez, B. 2005 Late Archean to early Paleoproterozoic global tectonics, environmental change and the rise of atmospheric oxygen. Earth Planet. Sci. Lett. 238, 156-171.

Bekker, A., Holland, H. D., Young, G. M. \& Nesbitt, H. W. $2003 \mathrm{Fe}_{2} \mathrm{O}_{3} / \mathrm{FeO}$ ratio in average shale through time: a reflection of the stepwise oxidation of the atmosphere. Geol. Soc. Am. 34, 83 abstract with programs

Bekker, A., Holland, H. D., Wang, P.-L., Rumble III, D., Stein, H. J., Hannah, J. L., Coetzee, L. L. \& Beukes, N. J. 2004 Dating the rise of atmospheric oxygen. Nature 427, 117-120. (doi:10.1038/nature02260)

Berner, R. A. 2004 The Phanerozoic carbon cycle: $\mathrm{CO}_{2}$ and $\mathrm{O}_{2}$. Oxford, UK: Oxford University Press.
Bjerrum, C. J. \& Canfield, D. E. 2002 Ocean productivity before about 1.9 Gyr ago limited by phosphorus adsorption on iron oxides. Nature 417, 519-562. (doi:10.1038/ 417159a)

Brasier, M., Mc Loughlin, N., Green, O. \& Wacey, D. 2006 Critical testing of the earliest cellular fossils and microtubules. Phil. Trans. R. Soc. B 361, 887-902. (doi:10.1098/ rstb.2006.1835)

Brocks, J. J., Buick, R., Summons, R. E. \& Logan, G. A. 2003 A reconstruction of Archean biological diversity based on molecular fossils from the 2.78-2.45 billion year old Mount Bruce Supergroup, Hamersley Basin, Western Australia. Geochim. Cosmochim. Acta 67, 4321-4335. (doi:10.1016/S0016-7037(03)00209-6)

Broecker, W. S. \& Peng, T.-H. 1982 Tracers in the sea. New York, NY: Eldigio Press.

Butterfield, N. J. \& Rainbird, R. H. 1998 Diverse organicwalled fossils, including "possible dinoflagellates," from the early Neoproterozoic of arctic Canada. Geology 26, 963. (doi:10.1130/0091-7613(1998)026<0963:DOWFIP > 2.3. $\mathrm{CO} ; 2)$

Canfield, D. E. 1998 A new model for Proterozoic ocean chemistry. Nature 396, 450-453. (doi:10.1038/24839)

Canfield, D. E. 2005 The early history of atmospheric oxygen. Annu. Rev. Earth Planet. Sci. 33, 1-36. (doi:10. 1146/annurev.earth.33.092203.122711)

Colman, A. S. \& Holland, H. D. 2000 The global diagenetic flux of phosphorus from marine sediments. In Marine authigenesis: from global to microbial (ed. G. R. Glenn, L. Prévôt-Lucas \& J. Lucas) SEPM Special Publication, vol. 66.

Conway Morris, S. 2006 Darwin's dilemma: the realities of the Cambrian 'explosion'. Phil. Trans. R. Soc. B 361, 1069-1083. (doi:10.1098/rstb.2006.1846)

Cook, P. J. \& McElhinny, M. W. 1979 A reevaluation of the spatial and temporal distribution of sedimentary phosphate deposits in the light of plate tectonics. Econ. Geol. 74, 315-330.

Cook, P. M. \& Shergold, J. H. (eds) 1986 Phosphate deposits of the world Proterozoic and Cambrian phosphorites, vol. 1, p. 386. Cambridge, UK: Cambridge University Press.

Dudley, R. 1998 Atmospheric oxygen, giant Paleozoic insects and the evolution of aerial locomotor performance. f. Exp. Biol. 201, 1043-1050.

Farquhar, J., Bao, H. \& Thiemens, M. 2000 Atmospheric influence of Earth's earliest sulfur cycle. Science 289, 756-758. (doi:10.1126/science.289.5480.756)

Farquhar, J., Wing, B. A., McKeegan, K. D., Harris, J. W., Cartigny, P. \& Thiemens, M. H. 2002 Mass-independent sulfur of inclusions in diamond and sulfur recycling on early Earth. Science 298, 2369-2372. (doi:10.1126/ science.1078617)

Feely, R. A., Trefry, J. H., Lebon, G. T. \& German, C. R. $1998 \mathrm{P} / \mathrm{Fe}$ and $\mathrm{V} / \mathrm{Fe}$ ratios in hydrothermal precipitates: potential new paleo-proxies for dissolved phosphate in seawater. Geophys. Res. Lett. 25, 2253-2256. (doi:10. 1029/98GL01546)

Frakes, L. \& Bolton, B. 1992 Effects of ocean chemistry, sea level, and climate on the formation of primary sedimentary manganese ore deposits. Econ. Geol. 87, 1207-1217.

Francois, R., Honjo, S., Krishfield, R. \& Manganini, S. 2002 Factors controlling the flux of organic carbon to the bathypelagic zone of the ocean. Global Biogeochemical Cycles 16, no. 4,1087. (doi:10.1029/2001GB001722)

Gellatly, A. M. \& Lyons, T. W. 2005 Trace sulfate in midProterozoic carbonates and the sulfur isotope record of biospheric evolution. Geochim. Cosmochim. Acta 69, 3813-3829. (doi:10.1016/j.gca.2005.01.019) 
Graham, J. B., Dudley, R., Aguilar, N. \& Gans, C. 1995 Implications of the late Paleozoic oxygen pulse for physiology and evolution. Nature 375, 117-120. (doi:10. 1038/375117a0)

Halverson, G. P., Hoffman, P. F., Schrag, D. P., Maloof, A. C. \& Rice, A. H. 2005 Toward a Neoproterozoic composite carbon-isotope record. GSA Bull. 117, 1181-1207.

Hayes, J. M. 1994 Global methanotrophy at the Archean-Proterozoic transition. In Early life on earth (ed. S. Bengtson). Nobel Symposium 84, pp. 220-236. New York, NY: Columbia University Press.

Hoffman, P. F. In press. On the glacial history of snowball earth: "exercising the imaginative muscle". S. Afr. F. Geol.

Hoffman, P. F. \& Schrag, D. P. 2002 The snowball Earth hypothesis: testing the limits of global change. Terra Nova 14, 129-155. (doi:10.1046/j.1365-3121.2002.00408.x)

Holland, H. D. 1984 The chemical evolution of the atmosphere and oceans. Princeton, NJ: Princeton University Press p. 582 .

Holland, H. D. 1994 Early Proterozoic atmospheric change. In Early life on earth (ed. S. Bengtson). Nobel Symposium, vol. 84, pp. 237-244. New York, NY: Columbia University Press.

Holland, H. D. 2002 Volcanic gases, black smokers, and the great oxidation event. Geochim. Cosmochim. Acta 66, 3811-3826. (doi:10.1016/S0016-7037(02)00950-X)

Holland, H. D. \& Beukes, N. J. 1990 A paleoweathering profile from Griqualand West, South Africa: evidence for a dramatic rise in atmospheric oxygen between 2.2 and 1.9 bybp. Am. F. Sci. 290-A, 1-34.

Horita, J., Zimmermann, H. \& Holland, H. D. 2002 Chemical evolution of seawater during the Phanerozoic: implications from the record of marine evaporites. Geochim. Cosmochim. Acta 66, 3733-3756. (doi:10.1016/ S0016-7037(01)00884-5)

Hu, G. X., Rumble, D. \& Wang, P. L. 2003 An ultraviolet laser microprobe for the in situ analysis of multisulfur isotopes and its use in measuring Archean sulfur isotope mass-independent anomalies. Geochim. Cosmochim. Acta 67, 3101-3118. (doi:10.1016/S0016-7037(02)00929-8)

Isley, A. E. \& Abbott, D. H. 1999 Plume-related mafic volcanism and the deposition of banded iron formation. F. Geophys. Res. 104, 15 461-15 477. (doi:10.1029/1999 JB900066)

Karhu, J. A. \& Holland, H. D. 1996 Carbon isotopes and the rise of atmospheric oxygen. Geology 24, 867-870. (doi:10.1130/0091-7613(1996)024<0867:CIATRO > 2.3. $\mathrm{CO} ; 2)$

Kasting, J., \& Ono, S. 2006. Paleoclimates: the first two billion years. In Major steps in cell evolution: evidence, timing and global impact. London: The Royal Society.

Kasting, J. F., Pavlov, A. A. \& Siefert, J. L. 2001 A coupled ecosystem-climate model for predicting the methane concentration in the Archean atmosphere. Orig. Life Evol. Biosphere 31, 271-285. (doi:10.1023/A:1010600401718)

Klaas, C. \& Archer, D. A. 2002 Association of sinking organic matter with various types of mineral ballast in the deep sea: implications for the rain ratio. Global Biogeochemical Cycles 16, no. 4, 1116. (doi:10.1029/2001GB001765)

Knoll, A. H., Javaux, E. J., Hewitt, D. \& Cohen, P. 2006 Geological perspectives on the early diversification of eukaryotic organisms. Phil. Trans. R. Soc. B 361, 1023-1038. (doi:10.1098/rstb.2006.1843)

Lane, N. 2002 Oxygen, the molecule that made the world, p. 374. Oxford, UK: Oxford University Press.

Logan, G. A., Hayes, J. M., Hieshima, G. B. \& Summons, R. E. 1995 Terminal Proterozoic reorganisation of biogeochemical cycles. Nature 376, 53-56. (doi:10.1038/ 376053a0)
Mao, J., Lehmann, B., Du, A., Zhang, G., Ma, D. \& Wang, Y. $2002 \mathrm{Re}-\mathrm{Os}$ dating of polymetallic Ni-Mo-PGE-Au mineralization in Lower Cambrian black shales of South China and its geologic significance. Econ. Geol. 97, 1051-1061. (doi:10.2113/97.5.1051)

Melezhik, V. A., Fallick, A. E., Rychanchik, D. V. \& Kuznetsov, A. B. 2005 Palaeoproterozoic evaporites in Fennoscandia: implications for seawater sulphate, the rise of atmospheric oxygen and local amplification of the $\delta^{13} \mathrm{C}$ excursion. Terra Nova 17, 141-148. (doi:10.1111/j.13653121.2005.00600.x)

Miller, K. G. \& Fairbanks, R. G. 1985 Oligocene to Miocene global carbon isotope cycles and abyssal circulation changes. In The carbon cycle and atmospheric $\mathrm{CO}_{2}$ : natural variations Archean to the present (ed. E. T. Sundquist \& W. S. Broecker), pp. 469-486. Washington, DC: American Geophysical Union.

Mojzsis, S. J., Coath, C. D., Greenwood, J. P., McKeegan, K. D. \& Harrison, T. M. 2003 Mass-independent isotope effects in Archean (2.5 to $3.8 \mathrm{Ga}$ ) sedimentary sulfides determined by ion microprobe analysis. Geochim. Cosmochim. Acta 67, 1635-1658. (doi:10.1016/S00167037(03)00059-0)

Nothold, A. J. G., Sheldon, R. P. 1986 Chapter 2. In Phosphate deposits of the world, vol. 1. Proterozoic and Cambrian phosphorites (ed. P. J. Cook \& J. H. Shergold). Cambridge, UK: University Press Cambridge.

Ono, S., Eigenbrode, J. L., Pavlov, A. A., Kharecha, P., Rumble III, D., Kasting, J. F. \& Freeman, K. H. 2003 New insights into Archean sulfur cycle from mass-independent sulfur isotope records from the Hamersley Basin, Australia. Earth Planet Sci. 213, 15-30. (doi:10.1016/ S0012-821X(03)00295-4)

Pavlov, A. A. \& Kasting, J. F. 2002 Mass-independent fractionation of sulfur isotopes in Archean sediments: strong evidence for an anoxic Archean atmosphere. Astrobiology 2, 27-41. (doi:10.1089/15311070275362 1321)

Pierson, B. K. 1994 The emergence, diversification, and role of photosynthetic bacteria. In Early life on earth (ed. S. Bengtson), pp. 161-180. New York, NY: Columbia University Press.

Porter, S. M. \& Knoll, A. H. 2000 Neoproterozoic testate amoebae: evidence from vase-shaped microfossils in the Chuar Group, Grand Canyon. Paleobiology 26, 360-385.

Porter, S. M., Meisterfeld, R. \& Knoll, A. H. 2003 Vase-shaped microfossils from the Neoproterozoic Chuar Group, Grand Canyon: a classification guided by modern testate amoebae. F. Paleontol. 77, 205-255.

Roy, S. 1992 Environments and processes of manganese deposition. Econ. Geol. 87, 1218-1236.

Roy, S. 1997 Genetic diversity of manganese deposition in the terrestrial geological record. In Manganese mineralization: geochemistry and mineralogy of terrestrial and marine deposits (ed. K. Nicholson, J. R. Hein, B. Bühn \& S. Dasgupta) Geological Society Special Publication, vol. 119.

Rozendaal, A. \& Stumpfl, E. F. 1984 Mineral chemistry and genesis of Gamsberg zinc deposit, South Africa. Trans. Inst. Min. Metall. Sect. B Appl. Earth Sci. 98, B161-B175.

Saltzman, M. R. 2005 Phosphorus, nitrogen, and the redox evolution of the Paleozoic oceans. Geology 33, 573-576. (doi:10.1130/G21535.1)

Schopf, J. W. 1994 The oldest known records of life: early Archean stromatolites, microfossils, and organic mattter. In Early life on earth (ed. S. Bengtson), pp. 193-206. New York, NY: Columbia University Press.

Schopf, J. W. 2006 Fossil evidence of Archaean life. Phil. Trans. R. Soc. B 361, 869-885. (doi:10.1098/rstb.2006. 1834) 
Shaffer, G. 1986 Phosphate pumps and shuttles in the Black Sea. Nature 321, 515-517. (doi:10.1038/321515a0)

Shen, Y., Canfield, D. E. \& Knoll, A. H. 2002 Middle Proterozoic ocean chemistry: evidence from the McArthur Basin, Northern Australia. Am. f. Sci. 302, 81-109.

Shields, G. \& Veizer, J. 2002 Precambrian marine carbonate isotope database: version 1.1. Geochem. Geophys. Geosyst. 3, 12. (doi:10.1029/2001GC000266)

Slack, J. F., Bekker, A., Rouxel, O. J. \& Lindberg, P. A. 2005 Suboxic deep seawater at ca. $1.74 \mathrm{Ga}$ : evidence from seafloor-hydrothermal jasper and iron-formation in the Jerome District, Arizona. National Meeting of the Geological Society of America, abstract with programs.

Summons, R. E., Bradley, A. S., Jahnke, L. L. \& Waldbauer, J. R. 2006 Steroids, triterpenoids and molecular oxygen. Phil. Trans. R. Soc. B 361, 951-968. (doi:10.1098/rstb. 2006.1837)

Watanabe, Y., Klarke, A. I., Poulson, S. \& Ohmoto, H. 2005 The absence of mass independent sulfur isotope fractionation in Archean sedimentary rocks: evidence for an oxic atmosphere? Earth System Processes 2, Calgary, Alberta, Canada, abstract with programs 34.

Wheat, C. G., Feely, R. A. \& Mottl, M. J. 1996 Phosphate removal by oceanic hydrothermal processes: an update of the phosphate budget of the oceans. Geochim. Cosmochim. Acta 60, 3593-3608. (doi:10.1016/0016-7037(96)00189-5)

Yamaguchi, K. 2002 Geochemistry of Archean Paleoproterozoic black shales: the early evolution of the atmosphere, oceans, and biosphere. Ph.D. thesis, The Pennsylvania State University.

Yang, W. \& Holland, H. D. 2003 The Hekpoort paleosol profile in Strata 1 at Gaborone, Botswana: soil formation during the Great Oxidation Event. Am. F. Sci. 303, 187-220.

Young, G. M., Von Brunn, V., Gold, D. J. C. \& Minter, W. E. L. 1998 Earth's oldest reported glaciation: physical and chemical evidence from the Archean Mozaan Group $(\sim 2.9 \mathrm{Ga})$ of South Africa. F. Geol. 106, 523-538. 